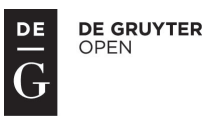

\title{
SUPERFICIARY RIGHT OF BUILDING: ORIGIN AND DEVELOPMENT in Central Europe
}

\author{
Pavel Petr ${ }^{1}$
}

\begin{abstract}
The Czech Republic has been dealing for the last four years with a legal revolution in the field of private law. A new Civil Code was adopted in 2012 and many new and forgotten legal figures were restored in the text of the code. An interesting example of forgotten legal figures is the superficiary right of building, which has again entered the legal order of the Czech Republic after a long one hundred years. Unlike the Act on the Superficiary Right of Building of 1912, the new Civil Code extends the scope of persons that may create the superficiary right of building to their land. This should eliminate the obstacle that has substantially limited its wider use. The superficiary right of building is not likely to become a legal concept very frequently seen in public registers. The aim of this paper is, therefore, a reflection on divided ownership and the purpose and genesis of the superficiary right of building in relation to its origins, as well as a prediction of future developments of this legal concept in the real estate market. To analyse the concept, the paper employs formal and legal methods (logical, grammatical and historical method). A comparative study is conducted in the spirit of the comparative method. The superficiary right of building is a suitable complement to the range of options of property rights offered by the new Civil Code. The author concludes that the use of the superficiary right of building, although not limited in comparison with the 1912 Act, will likely be less frequent and focused on longer-term projects.
\end{abstract}

\section{Keywords}

Superficiary Right of Building, Divided Ownership, Superficies Solo Cedit, Private Law

${ }^{1}$ Palacký University, Faculty of Law, 17. listopadu 18, 77111 Olomouc, Czech Republic, E-mail: pavel.petr@upol.cz. 


\section{Introduction}

East European countries are still dealing with the heritage of post-socialist legal orders. ${ }^{2}$ The lack of adequate law constitutes an obstacle for further market development. ${ }^{3}$ There are two major ways to solve this problem. The first is to make an amendment to the current law (e.g. civil code) and the second is to adopt new legislation. The "amendment" approach was used by the Polish, Czech and Slovak legislator. In contrast, the Hungarian legislator went for new legislation. Both methods have their benefits and disadvantages. The clearest way is to adopt new legislation with respect to the historical development of the country. The situation in the Czech Republic has shown the disadvantages of the "amendment" approach and the political situation in 2012 enabled the adoption of the new Civil Code. Many new and forgotten legal figures were restored in the text of the code. An interesting example of forgotten legal figures is the superficiary right of building, which has entered again the legal order of the Czech Republic after a long one hundred years.

The superficiary right of building is a re-established concept that has accompanied the superficiary principle since the days of Roman law, ${ }^{4}$ constituting its derivative. In the period of the Roman Republic, it was common to allow merchants to erect a building (e.g. a stand) on municipal land. This privilege was subject to annual rent (solarium). Superficies was protected by the praetor's interdictum. In the course of the development of superficies, the right also became capable of being transferred to another or inherited. Without the existence of superficies, the nature of the superficiary principle would prevent the efficient use of land and would lead to the need to create various partial exemption, which would affect the homogeneity of private law. The Czech Republic, Slovakia, Lithuania and partly Poland are the only European countries which have so far not applied the superficiary principle ${ }^{5}$, that is, a prescriptive enforcement of the Roman-law principle "superficies solo cedit". This re-introduced principle had been part of our law until derogated upon the effectiveness of the Interim Civil Code. ${ }^{6}$ The underlying reasons as well as a broader view of the superficiary principle have already been analysed in the field of jurisprudence. ${ }^{7}$ The predecessors of the superficiary right of building also include the German Platzrecht, which was subject to a special superficies payment (purkrecht) ${ }^{8}$ charged for the permission to build a house on a plot of the City Lord.

\footnotetext{
${ }^{2}$ Hamulák (2015).

${ }^{3}$ Ključnikov, Jünger (2013).

${ }^{4}$ Although superficies could not be an independent subject-matter of ownership right in Roman times. For more details, see Dvořák, Zoulík (2011).

${ }^{5}$ Eliáš (2008).

${ }^{6}$ However, for practical reasons, the superficiary right of building withstood its derogation until the adoption of the socialist Civil Code in 1964.

${ }^{7}$ For publications at the time of the principle's derogation, see, e.g. Novohradský (1951). For recent publications, see Petr (2012).

${ }^{8}$ Cf. the explanatory report to the draft Czechoslovak Civil Code (Sections 241-259) of 1937. For detailed information, see Von Waechter (1868).
} 
Austria adopted an act on superficiary right of building only in $1912^{9}$. Germany had seen the enactment of a similar regulation five years earlier. ${ }^{10}$ According to contemporary literature, a military conflict, together with the initial distrust of "novelty"11, constituted a paradigm shift in the expectations embodied in the concept by the legislators. Until the end of the Great War, there were only three cases of superficiary right of building in our territory ${ }^{12}$. To demonstrate the contemporary expectations underlying this concept, reference can be made to the works of the then leading experts. ${ }^{13}$ In addition, several works of recent literature can be mentioned. ${ }^{14}$

Unlike the Act on the Superficiary Right of Building of 1912, the new Civil Code extends the scope of persons that may create the superficiary right of building to their land, which should eliminate the obstacle that substantially limited its wider use during the First Republic. However, the issue here is not an attempt to maximize the occurrence of superficiary right of building, but rather to allow a plurality of private-law solutions of life situations with identical content. After all, the variety of different routes to a specific destination is intrinsic to private law. ${ }^{15}$ Therefore, the aim of this paper is a reflection on the purpose and genesis of the superficiary right of building, as well as a prediction of future developments of this legal concept in the real estate market.

\section{Cure for housing shortage}

The question of who has the right (locus standi) to establish the superficiary right of building on his/her land appears to be crucial. The original legislation (Act of 1912), and even some of today's foreign legal regulations (e.g. Poland) permit the establishment of a superficiary right of building only on land belonging to public corporations or religious organizations.

In order to understand the raison d'être of such limitations, it is necessary to consider the causes that led to the enactment of the superficiary right of building in the past. It is undisputed that the reasons why the superficiary right of building was adopted in the early twentieth century in Austria or Germany have a common denominator - housing shortages due to industrialization, which caused the migration of population to the cities, logically leading to the saturation of the housing market and to insufficient housing capacity. ${ }^{16}$ Given that demand grew primarily among low-income groups of the population and, as a result, could not be addressed by housing ownership, rental housing appeared to be the most appropriate option. ${ }^{17}$

\footnotetext{
${ }^{9}$ Effective from 15 June, 1912.

${ }^{10}$ Until then, the superficiary right of building was covered under Sections 1012-1017 of BGB; for details, see Huestedt (2010).

11 Pelikan (1937).

12 Ibid. (unfortunately, the sources do not indicate where they were established).

13 For example, Svoboda (1913), Krčmář (1946).

14 Zima (2015). Eliáš (2012); Bittner (1997); Bárta (2003).

15 Eliáš (2012).

16 Buriánek (1996).

17 Poláková (2006).
} 
The "housing question" was accompanied by increasing housing rents, which led to the creation of ghettos on the outskirts of cities, with the dominance of an economically weaker population (labourers, lower-ranking clerks or craftsmen). ${ }^{18}$ The quality as well as hygiene standards of these apartments were low. From the second half of the nineteenth century, the dismal housing conditions and high rents became an issue for legislators. However, the initiatives that led to the creation of self-help housing cooperatives were not answered.

The real onset of direct support for the construction of residential houses for the workingclass population begins only after the establishment of the Fund of the Emperor Franz Joseph I. (1908), which provided funds to building housing cooperatives of government employees to purchase or construct residential houses. The situation also improved thanks to the State Fund for the Care of Small Apartments, which provided guarantees for mortgages and also provided credit. This also led to increased interest from municipalities, whose share in the ownership of the housing stock was, however, rather negligible before the foundation of Czechoslovakia. ${ }^{19}$

It was at this time that the legislators resolved to adopt another of the above series of protectionist measures aimed at constructing apartment buildings with affordable rental housing: the enactment of superficiary right of building. The legislators expressly assumed the construction of family houses and houses with small apartments on the basis of the superficiary right of building. ${ }^{20}$ Using today's terminology, the superficiary right of building was understood as an instrument of State housing policy.

Given this clearly specified objective and taking into account the time this occurs, it was necessary to seek guarantees that the purpose of the superficiary right of building would not spin out of control and be used for market purposes (especially land speculation) instead of addressing an urgent social issue.

Here, it is worth reminding the reader that this particular situation could not have been solved by ownership housing ${ }^{21}$. First, this was because such apartments would have been unlikely to be affordable for those suffering from a housing shortage (although this may not necessarily be the case with small "social" apartments). ${ }^{22}$ More importantly, however, this was because there was no legal possibility of the real division of immovable things. ${ }^{23}$ The legislators limited the locus standi entities. The superficiary right of building was permitted to be created only by municipalities, counties, lands, the State and public funds

\footnotetext{
18 Jemelka (2009).

19 Poláková (2006).

${ }^{20} \mathrm{Cf}$. Annex 34 to shorthand protocol of the Austrian House of Lords of 1911.

${ }^{21}$ (referring to the ownership or co-ownership of an apartment).

${ }^{22}$ Cf. Svoboda (1909), stating that: “... hopefully, the time is not far when the advantages of [housing coownership] will be recognised, such advantages primarily consisting in the social significance of the possibility to provide broader social groups with access, however modest, to affordable municipal immovable property..." ${ }^{23}$ However, the imprecise wording of Section 361 of ABGB led to a diversity of views of the (non-)admissibility of real division of buildings in our country. The plurality of opinions disappeared along with Act no. 50/1879 r.z., on the division of buildings by material interests, whose Section 1 provided that "floor ownership" (Stockwerkeigentum) is inadmissible. Perhaps the only tolerated exception was the real division of houses in Prague's Jewish ghettos, permitted under the then Talmudic law; however, this was mainly due to the isolation of Jews in a small area and the need to ensure a certain legal form of housing (Svoboda, 1909).
} 
on their plots of land. Other authorised persons included churches, benefices, religious institutes and societies, and publicly beneficial institutes or associations. However, these were subject to public oversight, because they needed approval from the Land Office, stating that the superficiary right of building so created is in the public interest.

The legislators literally tailored the Act in favour of municipalities, ${ }^{24}$ allowing them, once again using today's words, to play the role of the drivers of regional housing policy and to regulate construction activities, as well as the prices of rental housing within their administrative limits. The leitmotif of the legislation involved (a) civil-law, (b) nationaleconomic, and (c) social reasons.

The European context of the time when the first Act on superficiary right of building was adopted is also interesting. While in countries such as France ${ }^{25}$ or Great Britain, ${ }^{26}$ the superficiary right of building (or, more precisely, a very similar legal concept) was commonplace, Austrian lands had a lack thereof. Combined with the fact that the competing Germany had had such legislation long before ${ }^{27}$, the motives of the legislators were obvious. The construction-law market in Germany was used to some extent as a model for the pioneers of the superficiary right of building in Prague (i.e. the members of the Association for the Superficiary Right of Buildings), who referred to it as an advanced and well-established market. ${ }^{28}$ Specifically, the areas around Frankfurt, Halle, Leipzig or the residential area Dahlem near Berlin were well known for the superficiary right of building. ${ }^{29}$ After all, it was even supported by Mr. Damaschke, the creator of the land reform. ${ }^{30}$

One must not forget that the Act on the superficiary right of building only applied in the Czech lands. It was not adopted in the Carpathian Ruthenia and Slovakia. The legislations were not unified until the adoption of the Act of $1947 .{ }^{31}$

In present day Europe, examples of the superficiary right of building are many. Let us present Amsterdam as an example. Since 1896 to the present (2014), not a single municipal plot of land has been sold. From the perspective of the Czech municipal privatization mania, this seems almost unbelievable. This approach demonstrates a different attitude to land ownership, as well as the issue of preserving values for future generations. Most of the land in Amsterdam is owned by the city and it is almost impossible to build in a manner other than superficiary right of building (Erfpacht) on municipal land.

As reported by Zima ${ }^{32}$, superficiary right of building has recently become very popular with German Federal Railways, which massively establish superficiary right of building to

\footnotetext{
24 Pelikan (1937).

${ }^{25}$ It is reported that plots of land in Paris beyond the city gates were given to the public for development, and after 77 years they were transferred back to the city of Paris.

${ }^{26}$ The explanatory reports to the Act on the superficiary right of building (1912, and literally also 1947) state that at the time of its adoption, a large number of houses in London were still built on land of another.

27 The Saxon Civil Code of 1863 instituted this right under the name Baurecht, or Kellerrecht. As indicated above, BGB then contains a section dedicated to Erbbaurecht, under in-rem rights.

${ }^{28}$ Kravák, Černý, Bartošek, Zelenka (1938).

29 Ibid. p. 41.

${ }^{30}$ Damaschke (1904).

31 Luby (2002).

32 Zima (2005).
} 
their land. It is also known in France (bail á construction). Its large-scale application can be seen in, e.g. Paris ${ }^{33}$, its use having a clearly urbanistic background. The superficiary right of building started up the real estate market in the conurbation, where municipal land was offered to developers. ${ }^{34}$ Similar to today, the range of persons entitled to erect a structure was not limited.

This indicates that the grounds to limit the range of owners that may establish the superficiary right of building were due to concerns over land speculation, thus of jeopardizing the purpose of the superficiary right of building (i.e. to provide cheap rental housing to low-income groups). The legislators relied on an unfounded assumption that the only "honest" owners are municipalities and religious organizations. One cannot deny that this assumption has a certain logic; however, the development of the superficiary right of building in Europe, where, with a few exceptions, the scope of owners is not limited, rather favours the more liberal approach. Therefore, abandoning the limitation of the scope of persons that may establish the superficiary right of building is very welcome. After all, in Poland ${ }^{35}$, which still has such a limitation in place, it hinders the real estate market, is being debated in academic circles and is often referred to as ideological. ${ }^{36}$

\section{Importance and purpose}

Returning back to the purpose of determining why superficiary right of building was established, one cannot avoid its socio-economic importance. The right was to act as a restraint on land speculation, and create positive downward pressure on rents, thus stimulating construction activity and consequently also leading to lower unemployment. The poor start and high expectations have already been mentioned. Until 1927, the superficiary right of building had not seen any substantial extension. However, 1927 saw the enactment of the Construction Activity Act, whose Section 43(2) made it possible to grant a state guarantee for the construction of family houses. The guarantee consisted of the State acting as a surety of a creditor for a loan (repayment of principal plus interest). ${ }^{37}$ In this way, for example, the Alexander Student Home (now Comenius Student Home in Prague 6) was built in Prague.

The high price of land was actually the biggest obstacle to construction activity at that time. It is reported that after the war and due to the economic crisis, the price of land rose more than 40 times (in the period 1918-1937). High initial costs made the construction of rental housing more expensive and led to their low profitability. In such a situation, the option to build on the land of another, without the initial cost of purchasing the land, moreover with the possibility to charge non-liquidation superficies payments, became more attractive. Once awareness, marginalised until then, was raised, ${ }^{38}$ the construction-law market slowly picked up. However, the acceleration was not dramatic. After all, even today I do not

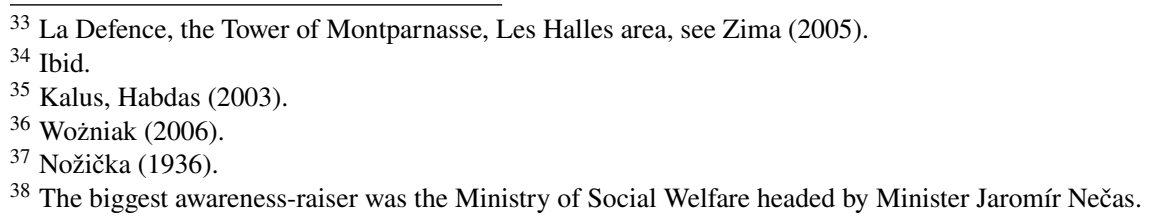


expect a massive expansion of superficiary right of building. Superficiary right of building was frequent in, e.g., the Ústí region. The former mayor of Ústi nad Labem, Mr Leopold Pölzl, stated that in the years 1923-1938, superficiary right of building was created on municipal land in 200 cases. The rent was set at a mutually advantageous level. For the first 30 years, the superficies payment was calculated as $2 \%$ of the assessed price of the land. In the last 50 years, it increased to 4\%. Such proceeds (CZK 109,822 per annum) were used to build the sewer system, repair other buildings and water mains. Mr Pölzl assumed that after 80 years, the superficiary right of building would be extended in favour of the legal successors of the builder. This de facto means that the in-rem right to structures constitutes divided ownership sui generis. Under the Third Reich, German municipalities established the superficiary right of building for 57-100 years, the superficies payment ranging between $1.5-4 \%$ of the price of land for the first 15 years, and $+2 \%$ thereafter. $^{39}$ Such payment may appear to be an appropriate "springboard" for setting contemporary superficies payments. Given that there is no experience with this concept, converting the price of today's land allows us to conclude that the superficiary right of building is not a fabulously profitable investment, but only a way in which to use unnecessary immovable property at small profit, while keeping the ownership rights. However, that does not change the fact that the amount of the superficies payment can be bound, e.g. to an inflation clause. Everything thus suggests that even today, superficiary right of building is more likely to be a tool for cities to address housing and urban policy. On the other hand, it is undeniable that legal practice may surprise us. However, I do not expect this to happen, taking into account international experience ${ }^{40}$.

One cannot also ignore the psychological factor. Superficiary right of building - as an immovable thing - may raise concerns of many investors about the actual content of their entitlement. The fact that the building is only part of the superficiary right of building only intensifies the problem. Therefore, the conceptual understanding of superficiary right of building as an immovable thing is possible only once we change the current way of looking at things in a legal sense (cf. Section 489 of the new Civil Code). ${ }^{41}$

On the other hand, this is really just a normative description of reality. Yes, it requires greater legal abstraction in defining and understanding the concept, but that should not be a problem. Although a broader conception of a thing is certainly not perfect, we are not the only ones with this problem. A wider definition of a thing in the legal sense is logically also contained in Austrian law. ${ }^{42}$ Section 285 of ABGB $^{43}$ regulates things as follows: "Every thing, which differs from the person and serves for the use of men, is called

\footnotetext{
39 Kravák, Černý, Bartošek, Zelenka (1938).

${ }^{40}$ Licher (2009); Habdas (1999).

41 For details, see Eliáš (1992).

42 The dualism of law in the territory of the Austro-Hungarian monarchy allowed the situation in Slovakia to be the opposite, i.e. that a thing was understood only as a physical object. The right, although a property subject, was not regarded as an intangible thing, see Rouček, Sedláček (1935).

43 Alles, was von der Person unterschieden ist, und zum Gebrauche der Menschen dient, wird im rechtlichen Sinne eine Sache genannt.
} 
a thing in the legal sense." ${ }^{44}$ This definition indicates conceptual elements of things ${ }^{45}$ : 1. difference from persons, 2. economic usefulness ${ }^{46}$ and 3. independent existence. ${ }^{47}$ Austrian legislators consider things in the legal sense to also include receivables or other property values (know-how, etc.), which are considered movable things. Immovable things are considered to include not only plots of land and buildings, but also superficiary right of building (Baurecht) ${ }^{48}$. Despite these positive-law regulations, First Republic doctrine inclined towards the material conception of things. ${ }^{49}$ The reasons can also be seen in the incompleteness of the unequivocal declaration throughout the text of the legal regulation, legitimizing the legislators' interpretation to be narrowed. ${ }^{50} \mathrm{~A}$ similar conclusion can be drawn in connection with the French Civil Code of 1804. As noted by Pelikánováa ${ }^{51}$, the situation in the Code Civil is more complicated (ambiguous definition, linguistic complexity); however, one can say that even the French conception is broader. This is more likely to be evident from jurisprudence rather than the code itself, because it also does not contain a definition of a thing. Conversely, a narrower conception is preferred by jurisprudence in Germany and Poland.

Public corporations were, along with churches, "good" owners in the eyes of the legislator; therefore, they were expected to emphasize low prices of superficiary payment so that the builder would be able to require low, albeit profitable, rents in the apartments in buildings constructed under the superficiary right of building.

The purpose of the superficiary right of building was also reflected in the possibility to arrange a relatively long duration of this right. While the draft Civil Code of 1937, or the Act of 1947, knew no maximum or minimum duration, ${ }^{52}$ the Act of 1912 firmly set out both limits. The minimum was 30 years, the maximum 80 . The reasons that led to the setting of the maximum limit consisted in the constitutional limits. Article 7 of the December Constitution forbade all relations arising from divided ownership which could not be bought back. The minimum limit was primarily targeted at quality architecture and construction. In compliance with Zima ${ }^{53}$, superficiary right of building can be considered to be used primarily for long-term projects.

\footnotetext{
44 Translation by Winiwarter (1866).

${ }^{45}$ It must therefore meet the objective teleological aspect; see Selucká (2007).

${ }^{46}$ Usefulness is judged according to the usual economic purpose, rather than marginal cases; see Eliáš (2007).

${ }^{47}$ Bydlinski (2002).

${ }^{48}$ Cf. § 6 Baurechtgesetz.

${ }^{49}$ Under the strong influence of Randa; see Randa (1922). It is similarly expressed by Krčmář (1946).

${ }^{50}$ Pelikánová (1995).

${ }^{51}$ Ibid. p. 3.

52 They only specified the temporary nature of the superficiary right of building. In doing so, they concluded that: social life can best determine the limits of its duration. This can be acknowledged. The question is why the legislators refrained from the same in the case of superficiary right of building of the early 21 st century.

${ }^{53}$ Zima (2014).
} 


\section{Conclusion}

East European countries are still dealing with the heritage of post-socialist legal orders. There are two major ways to solve this problem. The first is to make an amendment to the current law and the second is to adopt new legislation. A new Civil Code was adopted in 2012 in the Czech Republic and many new and forgotten legal figures were restored in the text of the code. An interesting example of forgotten legal figures is the superficiary right of building, which has again entered the legal order of the Czech Republic after a long one hundred years. As we are dealing with an old figure of the law, we have to put increased emphasis on its purpose and development.

The original purpose of the superficiary right of building was clearly a reflection of the principle of protecting the weaker party, when there were restrictions on the ownership entities (churches, municipalities), which were allowed to set up the superficiary right of building in order to protect the low-income groups for whom such buildings were intended. The current conception clearly lacks this aspect. However, it is the purpose of the legislation of the 1912 Act that may be an inspiration for public corporations and institutes at present. This does not only mean the State, municipalities or regions, but also churches, which will receive considerable property in restitution. Instead of the thoughtless sale of the land, they may look for its long-term, economically profitable use, while retaining the ownership right and, therefore, preserving value. As an example, let us refer to the Dutch case, which speaks for itself.

\section{Acknowledgements}

This article constitutes a partial outcome from the GACR project no. 15-08294S "Divided ownership and its Central European connotations and perspectives".

\section{References}

Bárta, J. (2003). K právu stavby vzniklému podle předpisů platných před současným občanským zákoníkem. Správní právo, 2003(4), 221-227.

Bittner, L. (1997). Rakouský zákon o právu stavby. Ad notam, 1997(4), 80-84.

Buriánek, J. (1996). Sociologie. Praha: Fortuna.

Bydlinski, F. (2002). In Rummel, P. et al. Kommentar zum Allgemeinem bürgerlichen Gesetzbuch in zwei Bänden. 3rd ed. Wien: Manz Verlag.

Damaschke, A (1904). Das Erbbaurecht und seine Bedeutung für die Gemeinden. München: Beck.

Dvořák, J., Zoulík, F. (2011). Superficies solo cedit a právo stavby. In Malý, K. et al. 200 let všeobecného občanského zákoníku. Praha: Wolters Kluwer.

Eliáš, K. (1992). Pozitivistická studie. Právník, 1992(8), 698-702.

Eliáš, K. (2007). Součást věci a příslušenství věci. Ad notam, 2007(4), 197-202.

Eliáš, K. (2008). Občanský zákoník. Velký akademický komentář. Praha: Linde.

Eliáš, K. (2012). Právo stavby. Obchodněprávní revue, 2012(10), 273-278.

Habdas, M. (1999). Użytkowanie wieczyste i jego znaczenie na polskim rynku nieruchomości. Prawo spółek, 1999(5), 49-55. 
Hamulák, O. (2015). Lessons from the "Constitutional mythology" or How to reconcile the concept of state sovereignty with European integration. Danube. Law and Economics Review, 2015(2), 75-90.

Huestedt, J. (2010). Einleitung. In: Hustedt V.; Ingenstau, J.; Drasdo, M.; Glade, J. Gesetz ubër das Erbbaurecht. Kommentar. 9th ed. Köln: Carl Heymanns Verlag.

Jemelka, M. (2009). Lidé z kolonií vyprávěji své dějiny. Ostrava: Repronis.

Kalus, S., Habdas, M. (2003). Czy nas na to stać? Gazeta Prawna, 2003(239), 20.

Ključnikov, A., Jünger, R. (2013). Barriers for foreign investment. Case of business logistics. Proceedings of Carpathian Logistics Congress, 2013, 139-145.

Kravák, A., Černý, V., Bartošek, B., Zelenka, J. (1938). Pro právo stavby. Praha: Spolek pro právo stavby.

Krčmár̆, J. (1946). Občanské právo II. Práva věcná. 3rd ed. Praha: Knihovna sborníku věd právních a státních.

Licher, T. (2009). Das Erbbaurecht - Königsweg für Kommunen. Verbandszeitschrift, 2009(1), 50-53.

Luby, S. (2002). Právo stavby. In: P. Blaho (ed.). Výber z diela a myšlienok. Bratislava: Iura edition.

Novohradský, L. (1951). Opustenie zásady „Superficies solo cedit“ a jeho dôsledky. Právný obzor, 1956(4), 348-355.

Nožička, J. (1936). Zákon o stavebním ruchu. Praha: V. Linhart.

Pelikánová, I. (1995). Úvaha o věcech v právním smyslu. Právní praxe v podnikání, 1995(11), 1-6.

Petr, P. (2012). Stará (nez)námá superficiální zásada. Právní rozhledy, 2012(10), 370-374.

Pelikan, V. (1937). Právo stavby jako prostředek k oživení stavebního ruchu. Praha: Unie Čsl. Družstev.

Poláková, O. (2006). Bydlení a bytová politika. Praha: Ekopress.

Randa, A. (1922). Právo vlastnické dle rakouského práva v pořádku systematickém. Praha: Česká akademie pro vědy, slovesnost a umění.

Rouček, J., Sedláček, J. (1935). Komentář k československému obecnému zákoníku občanskému a občanské právo platné na Slovensku a v Podkarpatské Rusi. Praha: V. Linhart. Selucká, M. (2007). Res iuris a instrumentum v rámci OZ a návrhu OZ. Časopis pro právní vědu a praxi, 200(4), 297-299.

Svoboda, E. (1909). O reálném dělení domů v obvodu bývalého pražského ghetta. Praha: Lidové družstvo tiskařské.

Svoboda, E. (1913). Nové právo k povrchu. Právník, 1913(52), 113-131.

Von Waechter, C. G. (1868). Superficiar - oder Platzrecht. 2. Aufl. Leipzig: Alexander Edelman.

Wożniak, C. (2006). Użitkowanie wieczyste. Warzsawa: C. H. Beck.

Zima, P. (2005). Stručný úvod do práva stavby. Právní rozhledy, 2005(8), 287-289.

Zima, P. (2014). K některým otázkám práva stavby podle nového občanského zákoníku. Právní rozhledy, 2014(5), 179-182.

Zima, P. (2015). Právo stavby. Praha: C. H. Beck. 